\title{
THE ASSESSMENT OF PLATELET FUNCTION
}

\author{
By A. A. Sharp, M.D., B.Sc. \\ Lecturer in Haematology, United Oxford Hospitals
}

The blood platelets have attracted the attention of several generations of clinicians, haematologists, physiologists and in recent years pharmacologists and biochemists.

Those who first described these cells, as separate elements of the blood, recognized that they played an integral part in the sequence of blood coagulation and in the mechanism of haemostasis (Hayem, I878, 1882, 1883 ; Bizzozero, 1882; Eberth and Schimmelbusch, I888). Early hypotheses of the mechanism of fibrin formation in shed blood included the platelets as taking part in the series of reactions (Morawitz, 1905; Nolf, 1908; Howell, r910; Bordet and Delange, r912).

The modern era of research in blood coagulation has confirmed the important part that platelets play in blood coagulation, and it is now known that platelets contain or have adsorbed on to their surfaces several factors which influence indirectly the rate and amount of fibrin formation. These may be summarized as follows:

Platelet Factor I accelerates the conversion of prothrombin to thrombin by thromboplastin.

Platelet Factor 2 accelerates the conversion of fibrinogen to fibrin by thrombin.

Platelet Factor 3, the major component of the platelet's contribution to intrinsic thromboplastin formation (Fig. I). This is a phospholipoid.

Platelet Factor 4 has antiheparin activity (Creveld and Paullsen, I951, I952; Creveld, r954; Alkjaersig, Abe and Seegers, 1955; Deutch, Johnson and Seegers, 1955).

Platelet Factor $\mathrm{I}$ has been shown to be adsorbed plasma Factor 5 (Hjort, Rapaport and Owren, 1955), but the other factors have a separate identity from plasma coagulation factors.

In addition to the above factors, the platelets carry small amounts of adsorbed antihaemophilic globulin, Christmas factor, prothrombin and fibrinogen (Bounameaux, I956; Seligman, 1957). It is possible that the platelets take part in the early stages of blood coagulation, and, having been activated by a product produced by interreaction between Hageman factor (Ratnoff and Colopy, 1955) and plasma thromboplastin ante-

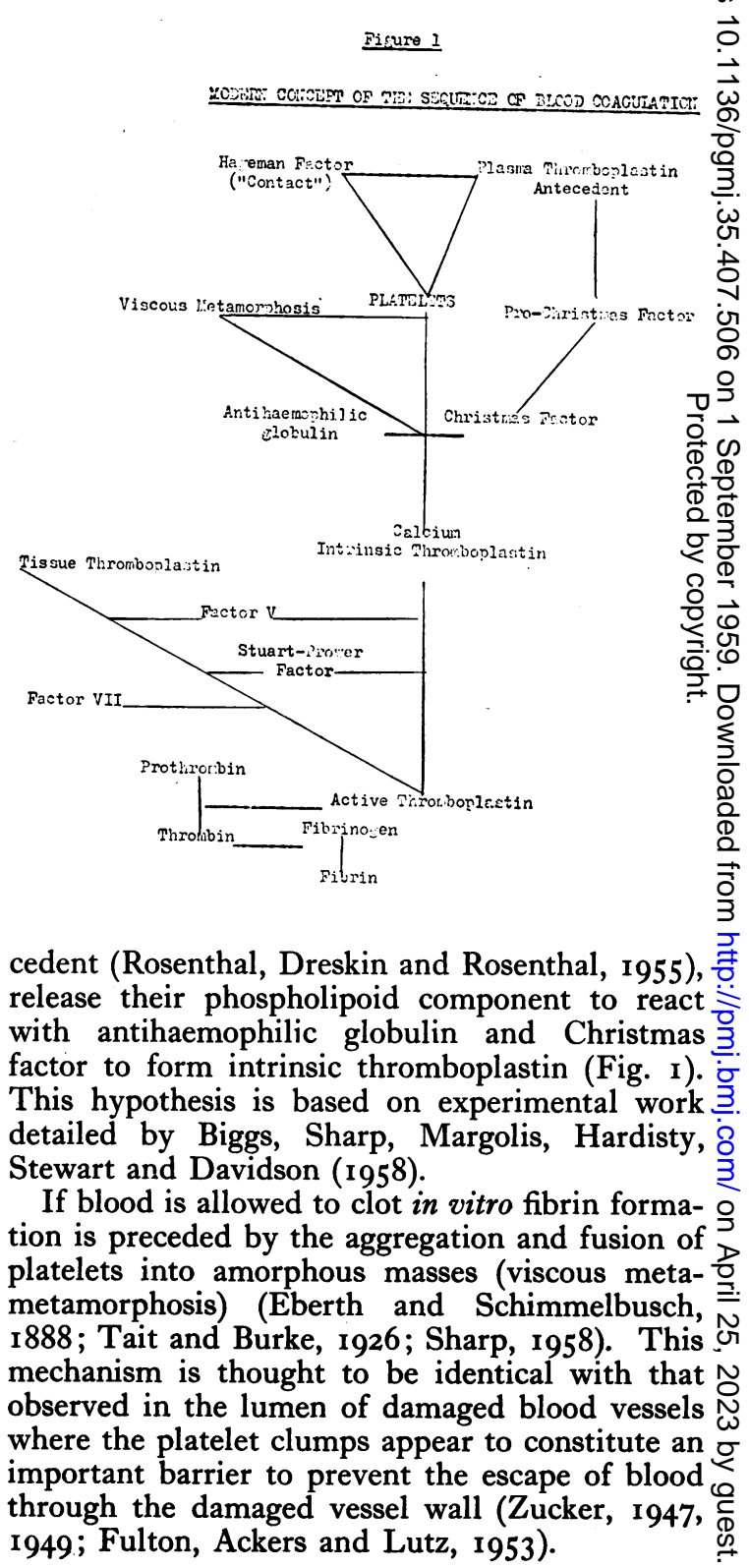


The role of platelets in haemostasis has been the subject of argument (Macfarlane, 194I), yet the evidence is in favour of their playing a major role in this mechanism either by virtue of their forming a mechanical block or by promoting fibrin formation at the site of injury. In recent years the platelets have been found to contain or carry pharmacologically active amines, namely, 5-hydroxytryptamine (5HT) (Zucker, Friedman and Rapport, 1954), adenosine triphosphate (ATP) (Born, 1956), adrenaline and nor-adrenaline (Weil-Malherbe and Bone, 1954). ${ }_{5} \mathrm{HT}$ has been identified as the vasoconstrictor principle in clotted blood (Zucker et al., I954; Hardisty and Stacey, 1955). Antifibrinolytic activity has also been detected in platelet extracts as has the enzyme acid phosphatase (Johnson and Schneider, 1953; Creveld, 1954; Stefanini and Murphy, 1956; Zucker and Borrelli, 1959).

It is evident, therefore, that any deficiency in platelet function must cause either inefficient coagulation of the blood, or a breakdown of the normal haemostatic mechanism, or both. Thus in any patient with an obscure haemorrhagic diathesis, if no abnormality of plasma factors can be detected, platelet function must be measured.

\section{Clinical States Associated with Abnormal Platelet Function}

The commonest type of platelet abnormality is a reduction of the absolute number of circulating cells (thrombocytopenia). The causes of this syndrome are multiple and will not be discussed here. Alternatively, a variety of clinical states have been described where, the numbers of platelets being normal, there has been bleeding of purpuric type similar to that associated with thrombocytopenia. This bleeding usually occurs spontaneously from mucous membranes, from internal surfaces of the body such as the renal tract, but does not result in massive tissue haemorrhages so characteristic of plasma factor defects. The number of different names applied to this non-thrombocytopenic syndrome has led to confusion (Soulier and Larrieu, 1954), but it is possible to divide this syndrome into two main sub-groups. One consists of cases of a hereditary haemorrhagic state, the only constant abnormal finding being a prolonged bleeding time (von Willebrand's syndrome). In all other respects platelets appear to be normal.

The other is a heterogenous group, where a hereditary or acquired functional deficiency of the platelets can be demonstrated. The terms "thrombopathy,' ' thrombocytopathia ' or ' thromboasthenia' have been applied to this group.

An increase in the number of circulating platelets is also associated with a similar clinical syn- drome. The term 'thrombocythaemia' is used to describe this condition.

\section{Methods for Assessing Platelet Function Numbers of Circulating Platelets}

The determination of the number of circulating platelets is the first essential in assessing platelet function. The direct counting method of Brecher and Cronkite (I950), using I per cent. ammonium oxalate, has been found to be reliable. The normal range varies with the method used, but usually is within the range $150,000-300,000$ cu.mm. Significant thrombocytopenia exists if the count is below $100,000 \mathrm{cu} . \mathrm{mm}$.

Indirect methods of counting have not been found to be so reliable as direct methods.

\section{Platelet Morphology}

This has been studied by various methods:

(I) In normal blood films stained by Romanowsky dyes (Bernard and Soulier, I948; Hardisty and Wolff, I955).

(2) By phase contast microscopy (Bessis and Tabuis, I955; Bernard, Caen and Maroteau, 1957).

(3) Electron microscopy (Bessis and Burstein, I948; Bloom, I95.5).

By any method it is difficult to define accurately the variations in normal morphology and only by examining large numbers of preparations is it possible to establish any criteria of normal and abnormal morphology. The most easily recognized abnormality is a marked variation in the shape and size of the platelets with the presence of definite giant forms which may vary from 5 to $20 \mu$ in diameter. This feature is easily determined by either of the first two methods which are also useful for determining the presence of platelet clumping or viscous metamorphosis in any given platelet preparation.

Variation in the minute structure of platelets is difficult to determine by direct or phase microscopy and resort must be made to electron microscopy. Normal platelets dried on the Formvar grid for electron microscopy show pseudopod or dentrite formation by the structureless hyalomere around the periphery of the cell. The absence of this phenomenon has been regarded as evidence of abnormal platelet morphology (Braunsteiner, Felliger and Pakesch, 1954; Ulutin, 1958), and has been described in cases of thrombopathia. This method also allows detailed study of platelet clumping and disintegration in viscous metamorphosis (Bloom, I955; Marx, Stich and Ehrhart, I956; Koppel, 1958).

As electron microscopy becomes more universally available for the routine study of platelet 
morphology, so more exact criteria of normal and abnormal morphology will be established.

Megakaryocyte morphology is abnormal in certain thrombocytopenic syndromes (Dameshek and Miller, 1946), but no definite abnormalities have been described in association with other functional platelet deficiencies apart from hyperplasia in the marrow of patients with thrombocythaemia (Hardisty and Wolff, 1955).

\section{Bleeding Time}

The best available test of primary haemostasis is the bleeding time. The role of platelets in haemostasis has already been discussed briefly and any significant deficiency of their function due to a reduction in numbers or due to a functional deficiency is usually accompanied by a prolongation of the bleeding time.

The method described by Ivy (Biggs and Macfarlane, I957) is more likely to reveal mild defects in the haemostatic mechanism than the Duke method. The normal range of the former method is $I$ to 6 minutes. In males the bleeding time is rarely prolonged beyond 4 minutes.

\section{Capillary Fragility}

Platelet dysfunction is often associated with abnormal fragility of the capillaries. Tests that measure this fragility cannot, however, be used to measure platelet function.

\section{Clot Retraction}

The retraction of fibrin after clotting has taken place is a function of normal intact and viable platelets and this phenomenon is partially or totally absent if the numbers of platelets in the clotting blood is reduced (Budtz-Olsen, I95I). Imperfect retraction in the presence of a normal number of platelets represents a functional defect of the platelets and examples have been recorded by Imerslund (1947), Alexander and Landwehr (1949), Jackson, Hartman and Conley (1953). The test of clot retraction in whole blood is simple to perform and provides consistent results in normal whole blood where the clot retracts by 40-6o per cent. in I hour after fibrin formation (Biggs and Macfarlane, 1957).

\section{Prothrombin Consumption Index}

It has already been described how platelets may play their part in the formation of thromboplastin and the consequent conversion of prothrombin to thrombin. Thus, if the numbers of circulating platelets are reduced or their function altered in respect of Platelet Factor 3, the amount of prothombin converted to thrombin, during coagulation of the whole blood, will be reduced (Quick, Shaneberg and Stefanini, 1949).
TABLE I

Prothrombin Consumption Index (Biggs andi Macfarlane, 1957) Modified To DEMONSTRATE Abnormal Platelet Function

To $0.5 \mathrm{ml}$. platelet-poor native plasma is added $0.5 \mathrm{ml}^{\circ}$ platelet-rich native plasma and the mixtures allowed to. clot at $37^{\circ} \mathrm{C}$. The amount of residual prothrombin is measured at 30 minutes and $I$ hour

\begin{tabular}{l|l|l|l|l}
\hline $\begin{array}{l}\text { Platelet-rich } \\
\text { native } \\
\text { plasma }\end{array}$ & Normal & Patient & Normal & Patient \\
\hline $\begin{array}{l}\text { Platelet-poor } \\
\text { native } \\
\text { plasma }\end{array}$ & Normal & Normal & Patient & Patient \\
\hline $\begin{array}{l}\text { The expected } \\
\text { Prothrom- } \\
\text { bin con- } \\
\text { sumption } \\
\text { index when } \\
\text { a platelet } \\
\text { defect } \\
\text { exists }\end{array}$ & & & \\
\hline
\end{tabular}

The test of prothrombin consumption described by Merskey (1950) is a sensitive indicator ofo platelet function provided no plasma coagulation factors necessary for thromboplastin formationes are absent.

Where whole blood shows abnormal prōthrombin consumption, a sensitive test of platert function has been evolved in this laboratogy using the same basis of prothrombin consumption $\overrightarrow{0}$ (see acknowledgments). The relative amounts $8 f^{G}$ residual prothrombin are estimated when mittures of normal and test platelet-rich and platelet-O poor native plasmas are allowed to clot at $37^{\circ} \mathrm{C}$. (Table I).

This test has been found to be a sensitive method of determining a reduction or a failure of release of Platelet Factor 3 .

\section{Thromboplastin Generation Test}

The ability of the platelets to generate normal amounts of thromboplastin in conjunction with윽 other plasma factors can be estimated by the above test (Biggs and Douglas, 1953). This has been the test most widely used in the measurement of platelet function and it is presumed that it does measure selectively the phospholipoid fraction or Platelet Factor 3 (Soulier and Larrieu, 1954; Nicola, 1954; Soulier. Larrieu and Wartelle, $\frac{D}{O}$ 1955; Braunsteiner, 1955; Bernard, Caen and․ㅡ․ Maroteau, 1957; Bonnin, 1957). Washed sus- N pensions of platelets from the patient are com- $N$ pared with a similar suspension prepared from $N$ normal blood. Care must be taken to ensure that the number of platelets in each suspension is similar and this may be achieved by comparing the relative opacity of the suspensions by use of a visual photometer or a photoelectric colorimeter. 

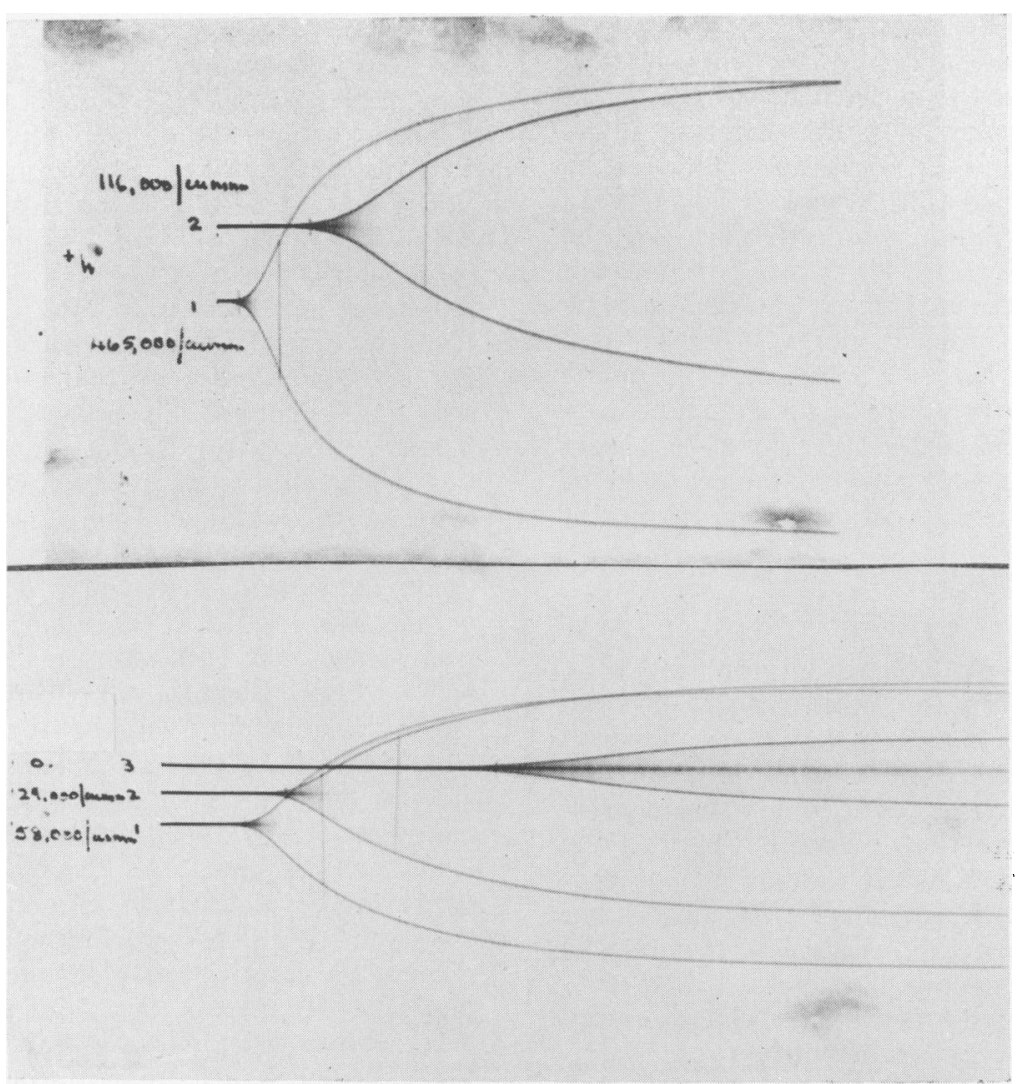

FIG. 2.-Thromboelastograph. These tracings show the effect of thrombocytopenia on the clotting of plasma as measured by the thromboelastograph. The figures to the left of the tracings indicate the numbers of platelets in the samples of plasma tested.

The thromboplastin generation test sometimes fails to detect mild defects of platelet function and may be sensitized by making progressive dilutions of both suspensions and retesting. Further sensitization may be achieved by lysing the platelets in distilled water. The failure of the lysed platelets to generate normal amounts of thromboplastin suggests that they are abnormally resistant to hypotonic solutions, and such resistance is thought to be characteristic of platelets in thrombopathy of a secondary type (Centingil, Ulutin and Karaca, 1958). If platelets, which show abnormal thromboplastin generation by conventional tests, show normal generation after lysis, the condition is probably an inherited abnormality (Ulutin and Karaca, 1956).

It has been found that the thromboplastin generation test is a less sensitive indicator of platelet dysfunction than the test for prothrombin consumption. This is possibly the result of partial platelet damage while preparing the washed platelet suspension.

\section{Platelet Activity in Serum}

O'Brien (1955) pointed out that serum contained platelet-like activity when added to platelet-free plasma and that this activity was not present in serum derived from platelet-free blood.

Alagille and Soulier (1957), modifying O'Brien's original method, determined the ability of serum containing platelet-like material to correct the prothrombin consumption when platelet-free plasma was allowed to clot. They confirmed that this activity depended on the number of platelets in the blood from which the serum was derived and in addition they found abnormal serum activity in some cases of thrombopathy. While this method may confirm platelet abnormalities detected by other methods, it is possible that this platelet-like activity of serum may be dependent on a factor or factors still to be defined and that cases where a defect can be demonstrated constitute a separate syndrome (Braunsteiner and Pakesch, 1956). 


\section{Thromboelastography}

The ingenious apparatus devised by Hartert (195I) has been used to measure platelet activity. It records photographically the onset of fibrin formation, the speed of increasing clot rigidity and the tenacity of the formed clot. These factors are all altered proportionally as the numbers of platelets in the clotting blood are diminished (Fig. 2), and similar findings may be found in cases of thrombopathy (Introzzi and Nicola, 1956).

Although an expensive apparatus, it can provide a convenient method of detecting possible platelet defects, but it does not obviate the necessity of performing other tests to define the culpability of these cells.

\section{Platelet Viscous Metamorphosis}

The ability of platelets to clump and fuse together prior to fibrin formation has already been described. This phenomenon has been shown to be a constant feature of normal platelet suspensions (Sharp, 1957a, 1958), and if absent must represent an abnormality of platelet function due either to an inherent defect of the cells or to a deficiency of certain coagulation factors (Biggs et al., 1958). Abnormalities in platelet clumping or viscous metamorphosis have been described in cases where abnormal function has been suspected (Soulier et al., 1955; Braunsteiner, 1955; SerefInceman, 1955, 1956; Centingil et al., 1958), but abnormalities of viscous metamorphosis do not necessarily occur in every case where abnormal platelet function can be detected by other tests (unpublished observations).

\section{Platelet Adhesiveness}

The ability of platelets to adhere to glass surfaces has been studied quantitatively by many workers, including Wright (1941), Weiner, Zeltmacher, Reich and Shapiro (1948), and Bounameaux (1958). The failure of the platelets to adhere to these surfaces has been thought to be a measure of platelet dysfunction (Moolten, Vroman and Vroman, 1949; Seref-Inceman, 1956). Bounameaux (1957) has suggested that adhesiveness and viscous metamorphosis are in fact synonymous and it is probable that the quantitative measurement of adhesiveness may also be a quantitative measurement of viscous metamorphosis. Viscous metamorphosis can, however, take place without the platelets showing any tendency to adhere to glass (personal observation). The test of adhesiveness may be a better measure of increased coagulability of the blood than of decreased platelet function (MacDonald and Edgill, 1957).

\section{Platelet Amines}

Platelet 5-hydroxytryptamine (5HT) and adeno-气̊ sine trophosphate (ATP) can be measured quan- 3

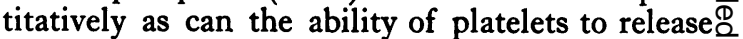
5-hydroxytryptamine on clotting. Further, the. ability of these cells to absorb $5 \mathrm{HT}$ from the $\vec{F}$ surrounding medium can also be assessed. The $\stackrel{\oplus}{+}$ vasoconstrictor action of $5 \mathrm{HT}$ has already been described and this amine is released from the platelets as they clump (Zucker and Borrelli, $\frac{\vec{\Phi}}{\widehat{D}}$ 1955). Doubt has been cast on the haemostatic $\stackrel{\mathbb{2}}{\circ}$ actions of ${ }_{5} \mathrm{HT}$ by Haverbach, Dutcher, Share, Tomch, Terry and Brodie (1957), who showed $\vec{\circ}$ that when circulating platelets were deprived of ${ }_{5} \mathrm{HT}$ by the action of Reserpine no abnormality $\vec{\omega}$ of haemostasis could be detected. Yet in some? cases of thrombocythaemia and thrombocyto- $\frac{0}{3}$ pathia abnormalities of platelet function have been associated with abnormally low levels of platelet $5 \mathrm{HT}$ (Bigelow, r 954 ; Zucker and Borrelli, ${ }^{\circ}$ 1956; Hardisty and Wolff, 1955; Quiry, Caen. ㄱ and Bernard, 1958). Platelets contain a large amount of ATP (Born, 1956), but the role of this 0 amine has not yet been defined. Two hypothesबड have been advanced: ATP may bind ${ }_{5} \mathrm{HT}$ selee $\vec{c}$ tively in the platelets as adrenaline is bound $\underset{0}{0}$ the adrenal glands, or alternatively it may responsible for the active uptake of ${ }_{5} \mathrm{HT}$ by the platelets. It may be that both are correct (Borm $\mathbb{Q}$ and Gillson, 1959; Born and Bricknel, I95\$. $\overrightarrow{0}$ Platelets once they are removed from the bof of and stored lose their amine content within 24 hours (Born, 1959), and this loss of activity mayo represent an important loss of platelet viability. This aspect of platelet physiology will be discussed later.

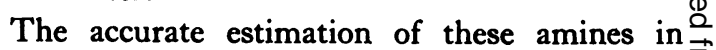
platelet extracts necessitates the use of complex techniques which are not readily available to the routine haematologist.

\section{Platelet Fragility Tests}

The lysis of platelets by hypotonic saline solutions has been observed (Gurevitch and Nelken, 1956; Morita, 1958) and increased resistance to lysis has been encountered in cases of thrombopathy (Ulutin and Karaca, 1956).

\section{Micro-electrophoresis}

The principles of electrophoresis of platelets ${ }^{-N}$ have been applied to platelet suspensions con- $\tilde{O}$ tained in special cells (Bigelow and Desforges, $N$

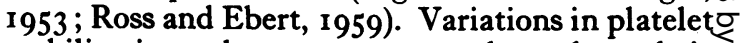
mobility in such a system must depend on theiro surface charge and, as this charge probably con- $\bar{\Phi}$ trols many of their activities, application of this? 
method to the problem of detecting abnormal platelet function is a worthwhile task.

Analysis of the platelet constituents, especially the protein and phospholipoid fraction, by conventional paper electrophoresis (Donner, Mach and Brancava, 1958) may lead to more specific determination of fractions than can be achieved by coagulation tests.

\section{Platelet Survival}

A crucial test of platelet viability is to determine whether they survive for their normal span in the blood of normal persons. Normal platelets tagged with radioactive di-isopropylfluorophosphate $\left(\mathrm{DFP}^{32}\right)$ and sodium chromate $\left(\mathrm{Cr}^{51}\right)$ have been found to survive for 9-II days in the circulation of normal individuals (Leeksma and Cohen, 1956; Aas and Gardner, 1958), so abnormal survival of platelets in the circulating blood of normal persons must represent diminished platelet viability. Whether such shortening of survival is characteristic of thrombopathia has yet to be determined.

\section{Platelet Transfusion}

In any case where a platelet defect is thought to be responsible for abnormal haemorrhage and where all attempts to measure this abnormality have failed, the therapeutic effect of the transfusion of normal platelets may be of value. Evidence of clinical and haemostatic improvement by such a transfusion confirms the presence of platelet dysfunction. The association of this test with a survival study of the transfused platelets may also be of value. If normal platelets fail to survive normally when transfused into the patient's circulation it does suggest that some factor external to the platelets is destroying or damaging them in the circulation (Sprague, Harrington, Lange and Shapleigh, 1952).

\section{Other Platelet Factors}

No case has yet been described where Platelet Factor 2 has been found to be deficient.

Creveld and Paullsen (1952) and Soulier and Larrieau (1954) report abnormalities in the amount of Platelet Factor 4 in association with other platelet defects.

Deficiencies of platelet antifibrinolytic activity have been reported in patients with abnormal platelet function (Stefanini and Murphy, 1956).

The accurate measurement of these latter factors is difficult to determine and there is little evidence that the trouble involved is worthwhile.

\section{Discussion}

Attempts to measure platelet function often produce equivocal results. This is undoubtedly due to the platelets being partially damaged during collection of the blood, the preparation of platelet-rich plasma and the preparation of platelet suspensions free from plasma. One major factor that has been found to cause platelet damage is faulty venepuncture technique and this variable is more likely to cause non-specific alterations of the platelets than any other (Sharp, 1957b). Such non-specific damage may result in abnormal platelets appearing to be normal (see thromboplastin generation test), or alternatively normal platelets may be so damaged by collection that they may appear to have abnormal function.

By far the best preparation for assessing platelet function is native plasma prepared in the cold without anticoagulant (Sharp, 1958). With this method it is possible to reduce non-specific factors to a minimum and to study viscous metamorphosis, platelet morphology and the ability of platelets to promote prothrombin consumption.

A study of the results of platelet function in patients with haemorrhagic symptoms suggests that certain clinical groups can be recognized. The following classification has been suggested (Biggs and Macfarlane, 1957) and has much to commend it:

I. The thrombocytopenic group is self-explanatory. It must be stressed that not all patients with thrombocytopenia show evidence of spontaneous haemorrhage or abnormal haemostasis, and it is probable that haemorrhagic symptoms develop only when thrombocytopenia and abnormal platelet function co-exist (Bonnin, 1957).

2. The von Willebrand's syndrome. In this syndrome a prolonged bleeding time is associated with normal numbers of platelets and normal platelet function, but now unusually low levels of antihaemophilic globulin appear to be the most constant defect encountered in this syndrome. Whether this latter factor, associated with a capillary defect, such as that described by Macfarlane (I94I), or with some as yet undefined plasma factor (Nilsson, Blomback, Jorpes, Blomback and Johansson, 1957), is responsible for the haemostatic defect has yet to be defined. On the evidence that exists at present this syndrome does not justify classification with other examples of platelet dysfunction.

3. Thrombopathia, thrombopathy, thrombocytopathia. This group is associated with normal numbers of platelets but with abnormal prothrombin consumption, decreased thromboplastinforming ability, and prolonged bleeding time, all other platelet function tests being normal. Two sub-divisions of this group exist, namely, (a) those patients with a definite familial haemorrhagic state, and (b) those where the platelet defect was secondary to a disease process such as uraemia, 
liver disease, scurvy and congenital heart disease (Lewis, Zucker and Ferguson, 1956; Lewis, Ferguson, Spaugh, Fresh and Zucker, 1957; Centingil et al., I958; Alagille, Heim, Guery, Passeleeq, Blondeau and Dubost, 1958). Evidence of thrombopathia is occasionally encountered in patients recovering from an episode of thrombocytopenia (Creveld, Liem Khe Ho and Veder, 1958).

4. Thromboasthenia. Coagulation function in this group is normal in respect of prothrombin consumption and thromboplastin generation, but clot retraction, agglutination or viscous metamorphosis are abnormal. In manv instances the bleeding time is also prolonged. The number of platelets is within normal limits.

5. Thrombocythaemia. Increased numbers of circulating platelets in this syndrome are frequently associated with abnormal thromboplastin generation and prothrombin consumption and a long bleeding time. Clot retraction is normal or greater than normal (Hardisty and Wolff, 1955).

Other cases are encountered which do not fit into this classification and these must be named after the specific platelet factor which is reduced in activity or absent.

A word must be said on the difference between normal platelet function and platelet viability. When platelet transfusions are given to improve haemostatic function in the thrombocytopenic patient, fresh blood, platelet-rich plasma or platelet concentrates must be used, as any preparation more than 24 hours old does not appear to confer any beneficial effect. Yet the platelets from preparations several days old and which have lost their ability to improve haemostasis, still function normally in respect of clot retraction, viscous metamorphosis, prothrombin consumption and thromboplastin generation (Mustard, r956; Sharp, unpublished observations). Therefore, unless our concepts of the beneficial effects of transfused platelets are wrong, normal platelet function and normal platelet viability are not synonymous terms. The only platelet factors that are known to deteriorate rapidly in the first 24 hours after removal from the body are $5 \mathrm{HT}$ and ATP (Born, 1959), and as they may play an important role in haemostasis, measurement of these amines may be a useful method of assessing platelet viability. The viability of platelets may also be estimated by measuring their metabolic activity in respect of oxygen consumption (Campbell, Small and Dameshek, 1956), but it is unknown whether the ability of platelets to consume oxygen and their ability to correct a defective haemostatic mechanism disappear at the same time.

In conclusion, the methods we have available for the measurement of platelet function are not entirely reliable, but in many instances they provide information of value in the assessment of clinical cases. Simpler and more rapid methods are needed to establish the presence of platelet defects in those cases of non-thrombocytopenig pliipura that are encountered. The modern trend of research would suggest that these new test. will be biochemical in nature rather than new tests of coagulation function.

\section{Summary}

Methods for measuring platelet function have been described and their inadequacies discusseds The need for new and more reliable tests is stressed.

\section{Acknowledgments}

I am indebted to Dr. M. Willoughby, Radcliffe Infirmary, Oxford, for permission to publista. details of this modification of the prothrombing consumption test.

\section{BIBLIOGRAPHY}

AAS, K. A., and GARDNER, F. H. (1958), $\mathcal{f}$. clin. Invest., 37, 1257 ALAGILLE, D., and SOULIER, J. P. (1957), Rev. Franfaise 2, 231 .

ALAGILLE, D., HEIM, R., GUERY, J., PASSELEEQ, BLONDEAÚ, J., and DÜBOST, Ch. (1958), Ibid., 3, 32.

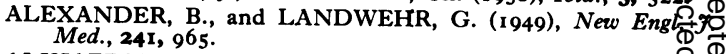
ALKJAERSIG, N., ABE, T., and SEEGERS, W. H. (1920)

BERNARD, J., and SOULIER, J. P. (1948), Sem. Hop. Paris, 97ᄍ I BERNARD, J., CAEN, J., and MAROTEAU, P. (1957), Hémat., 12, 222.

BESSIS, M., and BURSTEIN, M. (1948), Ibid., 3, 48.

BESSIS, M., and TABUIS, J. (1955), Ibid., ro, 753 .

BIGGS, R., and DOUGLAS, A. S. (1953), f. clin. Path., 6, 23.

BIGGS, R., MACFARLANE, R. G. (1957), 'Human Bloo Coagulation and its Disorders,' Blackwell Scientific Publicas tions, Oxford.

BIGGS, R., SHARP, A. A., MARGOLIS, J., HARDISTY R. M., STEWART, J., and DAVIDSON, 'W. M. (I958) Brit. F. Haemat., 4 , 177.

BIGELOW, F. S. (1954), f. Lab. clin. Med., 43, 759.

BIGELOW, F. S., and DESFORGES, J. F. (1953), Amer. F. Med. I4, 495 .

BIZZOZERO, G. (1882), Virchows Arch., 90, $26 \mathrm{I}$.

BLOOM, G. (1955), Z. Zellforsch., 42, 365.

BONNIN, J. A. (1957), Aust. Ann. Med., 6, 196.

BORDET, J, and DELANGE, J. (I, 657.

BORN, G. V. R. (1956), Biochem. f., 62, 33.

BORN, G. V. R. (I 959), personal communication.

BORN, G. V. R., and GILLSON, R. E. (1959), f. Physiol., in press BORN, G. V. R., and BRICKNEL, J. (r959), Ibid., in press.

BOUNAMEAUX, Y. (1956), Rev. Franfaise, $2,52$.

BOUNAMEAUX, Y. (1957), Actes 2nd Symp. Found. Baldacci, Lisbon, p. 87

BOUNAMEAUX, Y. (1958), Mém. Acad. roy. Méd. Belg., 3, I 1 .

BRAUNSTEINER, H. (1955), Wien. Z. inn. Med., 36, $42 \mathrm{I}$. BRAUNSTEINER, H., FELLIGER, K., and PAKESCH, F@.
(I954), Blood, 9, 595.

BRAUNSTEINER, H., and PAKESCH, F. (1956), Ibid., I1, $965 . \mathrm{N}$ BRECHER, C., and CRONKITE, E. P. (1950), f. appl. Physiol. 3, 365 . BUDTZ-OLSEN, O. E. (1951), 'Clot Retraction,' Blackwellî
Scientific Publications, Oxford.

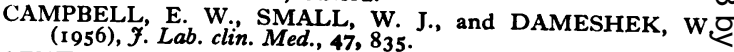

CENTINGIL, A. I., ULUTIN, O. N., and KARACA, M. (1958), Brit. F. Haemat., 4, 350.

CREVELD, S. (1954), Acta haemat. (Basel), 12, 229.

CREVELD, S., and PAULLSEN, M. M. P. (1951), Lancet, ii, 242. 
CREVELD, S., and PAULLSEN, M. M. P. (1952), Ibid., i, 23. CREVELD, S., LIEM KHE HO, and VEDER, H. A. (1958), Acta haemat. (Basel), 19, 199.

DAMESHEK, W., and MILLER, E. B. (1946), Blood, I, 27.

DEUTCH, E., JOHNSON, S. A., and SEEGERS, W. H. (1955), Circulation Res., 3, I 10.

DONNER, V. I., MACH, O., and BRANCAVA, S. (1958), Acta haemat. (Basel), 20, 369 .

EBERTH, J. C., and SCHIMMELBUSCH, C. (1888), Virchows Arch. path. Anat., 103, 39.

FULTON, G. P., ACKERS, R. P., and LUTZ, B. R. (1953), Blood, 8, 140.

GUREVITCH, J., and NELKEN, D. (1956), Ibid., 10, 924

HARDISTY, R. M., and STACEY, R. S. (1955), f. Physiol., I30, 7 II.

HARDISTY, R. M., and WOLFF, H. H. (1955), Brit. F. Haemat., $1,390$.

HARTERT, H. (195I), Z. ges. exp. Med., 117, 189.

HAVERBACH, B.J., DUTCHER, T. F., SHARE, P. A., TOMCH, E. G., TERRY, L. L., and BRODIE, B. B. (r957), New Engl. f. Med., 256, 343 .

HAYEM, G. (1878), C. R. Acad. Sci. U.R.S.S., 86, 58.

HAYEM, G. (1882), Ibid., 95, 18.

HAYEM, G. (1883), Ibid., $97,458$.

HJORT, P., RAPAPORT, S. I., and OWREN, P. A. (1955), Blood, IO, II39.

HOWELL, W. H. (1910), Amer. F. Physiol., 26, 453.

IMMERSLUND, O. (1947), Acta paediat. (Uppsala), 34, 315.

INTROZZI, P., and NICOLA, P. DE (1956), Sci. med. ital., 4, 656.

JACKSON, D. P., HARTMAN, R. C., CONLEY, C. I. (1953), Bull. Fohns Hopk. Hosp., 93, 370.

JOHNSON, S. G., and SCHNEIDER, C. L. (1953), Science,

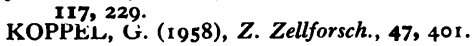

LEEKSMA, C. H. W., and COHEN, J. A. (1956), f. clin. Invest., 35, 964 .

LEWIS, J. H., FERGUSON, J. H., SPAUGH, E., FRESH, J. W., and ZUCKER, M. B. (r957), Blood, 12, 84.

LEWIS, J. H., ZUCKER, M. B., and FERGUSON, J. H. (1956), Ibid., 11,1073 .

MACDONALD, L., and EDGILL, M. (1957), Lancet, ii, 457.

MACFARLANE, R. G. (1941), Quart. F. Med., 34, I.

MARX, R., STITCH, W., and EHRHART, H. (1956), Proc. VIth Int. Cong. Haemat., p. 560.

MERSKEY, C. (1950), f. clin. Path., 3, 130.

MOOLTEN, S. E., VROMAN, L., and VROMAN, G. M. S. (1949), Amer. \%. clin. Path., 19, 814.

MORAWITZ, P. (1905), Ergebn. Physiol., 4, 307.

MORITA, H. (1958), 'Blood Platelets in Chemical Medicine,' Tokyo.
MUSTARD, J. F. (1956), Brit. F. Haemat., 2, 17.

NICOLA, P. DE (1954), Rev. Hémat., 9, 536.

NILSSON, I. M., BLOMBACK, M., JORPES, E., BLOMBACh, B., and JOHÄNSSON, S. A. (1957), Acta med. scand., 159, 179.

NOLF, P. (1908), Arch. int. Physiol., 6, 1.

O'BRIEN, J. R. (1955), Brit. F. Haemat., 1, 223.

QUICK, A. J., SHANEBERGE, J. N., and STEFANINI, $\boldsymbol{N}_{\text {. }}$ (1949), Amer. F. med. Sci., 217, 198.

QUIRY, D., CAEN, J., and BERNARD, J. (1958), Rev. Frangaise, 3, 477.

RATNOFF, O. D., and COLOPY, J. E. (1955), f. clin. Invest., 34, 602 .

ROSENTHAL, R. L., DRESKIN, O. H., and ROSENTHAL, N. (1955), Blood, ro, 120.

ROSS, S. W., and EBERT, R. V. (1959), F. clin. Invest., 38, 155.

SELIGMAN, M. (1957), C. R. Acad. Sci. U.R.S.S., 224, 2192.

SEREF-INCEMAN (1955), Sang, 26, 190.

SEREF-INCEMAN (1956), Forum Med., 2, 105.

SHARP, A. A. (1957a), 'Actes 2nd Symposium Foundation Baldacci,' Lisbon, p. 72.

SHARP, A. A. (1957b), 'Physiological and Antigenic Properties of Blood Piatelets,' p. 76, thesis for degree of M.D., University of Edinburgh.

SHARP, A. A. (1958), Brit. F. Haemat., 428.

SOULIER, J. P., and LARRIEU, M. J. (1954), Rev. Hémat., 9, 77.

SOULIER, J. P., LARRIEU, M. J., and WARTELLE, O. (I955), Acta haemat. (Basel), 14, 160.

SPRAGUE, C. C., HARRINGTON, W. J., LANGE, R. D., and SHAYLEIGH, J. B. (1952), $\mathfrak{f}$. Amer. med. Ass., 150, 1193 .

STEFANINI, M., and MURPHY, I. S. (1956), f. clin. Invest., 35, 355 .

TAIT, J., and BURKE, H. E. (1926), Quart. F. exp. Physiol., I6, 141 .

ULUTIN, O. N. (1958), Lancet, 11, $59 \mathrm{I}$.

ULUTIN, O. N., and KARACA, M. (1956), Forum Med., 4, 257.

WEIL-MALHERBE, H., and BONE, A. D. (1954), Nature, Lond., I74, 557 .

WEINER, M., ZELTMACHER, K., REICH, C., and SHAPIRO, S. (I948), Blood, 3, 1275 .

WRIGHT, H. P. (1941), F. Path. Bact., 53, 255.

ZUCKER, M. B. (1947), Amer. F. Physiol., 148, 275.

ZUCKER, H. D. (1949), Blood, 4, 631 .

ZUCKER, M. B., FRIEDMAN, B. K., and RAPPORT, M. M. (1954), Proc. Soc. exp. Biol., N.Y., 85, 282.

ZUCKER, M. B., and BORRELLI, J. (1955), f. appl. Physiol., 7,425 .

ZUCKER, M. B., and BORRELLI, J. (1956), Amer. F. clin. Path.,

ZUCKEK, M. B., and BORRELLI, J. (1959), F. clin. Invest., 138, 148 .

Bibliography from page 505-Y. W. Stewart, M.B., B.S., and P. F. Crosland-Taylor, M.B., B.Chir. BIBLIOGRAPHY

ALFEROW, S. (1884), Arch. Physiol. Norm. Path., 3, 269.

BERKSON, J., MAGATH, T. B., and HURN, M. (1940), Amer. F. Physiol., 128, 309.

BIGGS, R., and MACMILLAN, R. L. (1948), f. clin. Path., I, 269, 288.

BRACHETT, R. J.., MATTERS, C. F., and OLSON, B. F. (1953), Amer. $\mathscr{f}$. clin. Path., 23, 731.

BRECHER, G., SCHNEIDERMAN, M., and WILLIAMS, G. Z. (1956), Amer. F. clin. Path., 26, 1439.

BURKER, K. (1911), Arch. ges. Physiol. (Pflügers Archives), 142, 337.

COOK, H. F. (1952), Brit. F. applied Phys., 3, 249.

COOKE YARBOROUGH, E. H., and WHYARD, R. E. (1954), Brit. F. applied Phys., 5, Suppl. 3, S. 147.

CRAMER, A. (1855), quoted from Plum. Nederlandisch Lancet, 3rd Ser., 4, 453 .

CROSLAND-TAYLOR, P. J. (1953), Nature (Lond.), 171, 37.

CROSLAND-TAYLOR, P. J., STEWART, J. W., and HAGGIS, G. (1958), Blood, 13, 398.

DANNINGEN, K., and GRANT, E. H. (1958), Atom Praxis, 4 (10), Oct. 1958.

GOWERS, W. K. (1877), Lancet, ii, 797.

HAYEM, G., and NACHET, A. (1875), C.R. Acad. Sci., Paris, 80, 1083 .
HIRSCH, F. G., and TEXTER, E. C. (1950), Blood, 5, $1017,1036$. LAGERCRANTZ, C. (1952), Acta physiol. scand., 26, Sup. 93.

MACFARLANE, R. J., PAYNE, A. M. M., POOLE, J. C. F. TUMLINSÓN, A. H., and WOOLF, H. S. (1959), Brit. $\ddot{\mathfrak{y}}$ Haemat., 5, 1 .

MATTERN, C. F., BRACHETT, F. S., and OLSON, B. J. (1957), f. applied Physiol., 10, 56.

MOLDAVAN, A. (1934), Science, 80, 188.

OLIVER, G. (1896), F. Physiol., 19, Proc. Physiol. Soc. XVI.

PLUM, P. (1936), Acta med. scand., 90, 342.

PONDER, E. (1935), Amer. F. Physiol., 111, 99.

ROBERTS, F., and YOUNG, J. S. Z. (i952), The Proc. Instn. elect. Engrs., 99, Pt. IIIA, No. 20.

STEWART, G. N. (1897), f. Boston Soc. M. Sc. No. 16, 18, quoted by Stewart.

STEWART, G. N. (1899), F. Physiol., 24, 356.

STUDENT (1907), Biometrika, 5, $35 \mathrm{I}$.

VIERODT, K. (1852), Arch. Physiol. Heilk., I1, 26, $327,854$.

WAGNER, R. (1838), ' Nachtrage fur vergleichenden Physiologie des Blutes ', Leipzig.

WELCHER, H. (1854), Vjachr. Prakt. Heilk. (Prague), 44, 11.

WHITLOCK, J. H. (1947), Blood, 2, 463.

WILSON, T. M. (1905), Amer. F. Physiol., 13, 139. 